\title{
Portuguese castles: the territory and the community
}

\author{
J. Faria \\ Universidad de Alcalá, Spain
}

\begin{abstract}
This paper intended to analyse the relation between the heritage interventions on Portuguese castles, from 2001 onwards, and the context in which they are integrated, namely on the impact of these heritage interventions on local trade and the participation of the local communities in the decision-making process.

Heritage is no longer a process of construction of identity(ies), having become instead a series of artefacts and cultural practices categorized and managed by a specific circle of experts. This situation led to a progressive creation of new categories tending to accommodate the multiple meanings of the heritage concept to different non-western cultures; a phenomenon that led into a crisis of accumulation of heritage that poses considerable challenges in terms of a nation's financial management. In addition to this, there was a large increase in the number of visits to heritage sites since the second half of the twentieth century, a fact that was expected to generate economic benefits to the region or the nation's development.

The results achieved by the study showed that in spite of the different contexts there were no significant differences regarding the concept, programme and use of the heritage interventions, reflected in the poor adequacy to the context in which they are integrated, especially concerning the availability of financial means to secure their maintenance and the anticipated beneficial economic impact. To solve the problems identified above, higher involvement of the local communities could be an important step forward towards sustainable maintenance.

Keywords: heritage, castles, territory, community.
\end{abstract}




\section{Introduction}

Medieval Portuguese military architecture is associated to a national strategy of definition of boundaries and the settlement of territory, as well as to the economic and administrative control of it. In this way, medieval Portuguese military architecture has a significant importance in the national territory, both in terms of its impact and image in the landscape as well as in the collective memory. In spite of a strict defensive function, there are several periods in Portuguese military history in which many castles stopped serving as practical and functional military structures. Because of this, a progressive lack of maintenance and care began. The awareness of this was not lost on some intellectuals of the nineteenth century, namely Alexandre Herculano, as highlighted by Tomé [1], and led to the creation of national legislation and institutions. In the twentieth century, changes to both the regulation of the heritage and its significance to the national context occurred as a consequence of the implementation of the Estado Novo, a dictatorial regime in effect in Portugal between 1933 and 1974. The monuments, named national monuments, were considered as live documents of certain historical periods of the national history which the Estado Novo assigned as important, as Neto [2] says. So, the national monuments were conceived as having a pedagogical role. In this context, castles had a significant importance because these structures are associated with the foundation and the definition of the actual boundaries of the country. Furthermore, the singularities of the local contexts in which the castles are integrated were subjugated to achieve a national action of valorisation and restoration of the castles within the landscape. At the same time, outside of the Portuguese context, considerable renovation and reconstruction campaigns were taken on with monuments, groups of buildings and sites, in consequence of their destruction during the Second World War. Those campaigns were carried out according to theories developed up until that time, in which, and as Aguiar [3] states, actions of reinvention and renovation were taken. The lack of consistent criteria on the heritage interventions led to several critiques and ultimately, to new approaches, reflected on the editing of the Venice Charter, in 1964. This Charter presents principles of a new approach that considered and included the both urban and rural sites (art. 1) and the importance of maintenance as a conservation action, in which the intervention programme must be adaptable to heritage artefact specifications (art. 4). Within the Portuguese military architectural context, after the interventions of the 1940s and 1950s until the 1990s, isolated interventions were carried out in which a few castles were submitted to a new use, already according to the Venice Charter, as hotels, museums and leisure programmes with a contemporary approach, according to Pereira [4]. This action was, at the same time, a response to the increase of public interest in heritage sites, in which castles had to adapt to the reception and public fruition needs as well as the economic benefits which they were expected to generate. As Harrison [5] states, these factors have had a direct impact on the way heritage is managed and categorized.

However, these intervention practices connected with an economic expectation often has a large impact on the local communities and their space and leads to the loss of other heritage values, as Santos [6] states. Consequently, the excessive 
utilization of functional programmes focused on the public fruition caused an intervention approach which has been put into question. According to Folgado [7], the period of more heritage typologies was surpassed to give way to a merged heritage on the territory, where knowledge and the practices converge and depend on various social actors. In this way, the Cracovia Charter indicates larger intervention possibilities which depends on the singularities of each social and cultural context and emphasizes the participation of the local communities, as Fernandes [8] states. However, and as will be shown ahead, this fact has not been taken into consideration when it comes to contemporary interventions of Portuguese castles. Although it is widely recognised that the economic expectation associated to the heritage sites signifies "a point of no return" or that a break-even cost point cannot be achieved in contemporary society, questions are raised in relation to the loss of other heritage values due to the intervention programmes focused on wealth increase and public fruition and their effectiveness in the regional or local contexts. In the military architectural context, because Portuguese castles are intrinsic to a specific context, the intangible and social heritage as well as other heritage dimensions have a large importance and should be considered on the heritage interventions of those structures. By this way, a heritage intervention project on Portuguese military architecture will have to include several aspects, for instance, the singularities of the local context and the community. Within the contemporary Portuguese panorama, the heritage interventions on castles are, generally, isolated architectural interventions, limited by pre-existent structure specificities as well as the urban space of the nearby surroundings. Due to few limitations when the heritage intervention is focused on the pre-existent structure, there is evidence, in a general way, of the authorship reinforcement as well as a conceptual and shape design freedom. As a result, the participation of different social actors, including the inhabitants, is not possible. In this way, this study intended to reflect upon the contemporary practice and theory dichotomies in relation to the heritage conservation of medieval Portuguese military architecture and to achieve some guidelines to give way to new approaches as a different response to the singularities and needs of each context. This approach is only possible when heritage is considered to have an active role on the construction of identity(ies), a matter dealt with by Smith [9] in a very elucidative way. In the same way, Jokilehto [10] consider that contemporary conservation "demands courage to undertake sustainable human development within the reality and the potential of existing cultural, physical and environmental recourses". This aspect must be taken into consideration in the forthcoming heritage interventions as well as their sustainability according to the local available recourses.

\section{Some methodological considerations}

Firstly, a documental analysis of the literature review was carried out, mainly of the most recent literature, which presented new approaches concerning both the concept of heritage and heritage intervention. This was done to define some premises which would serve as guidelines to the analysis of the heritage interventions on castles in their relation to a specific context. It was not possible 
to conduct a study of all contemporary heritage interventions on Portuguese castles due to the existence of a large number of said interventions. Thus, a selection of the heritage interventions was made by using the definition of a time framework and by selecting those which presented the characteristics shown through the theoretical fundamentals. In order to respond to the objectives of the present study a qualitative methodology was carried, through the case studies, according to Yin [11]. To analyse the most recent heritage interventions on Portuguese castles was necessary to observe the occurred changes during the last decade of the twentieth century as well as the main characteristics introduced in that period. These characteristics were some of the starting points of the analysis of interventions of the case studies. The case studies interventions were also analysed under the new approaches of the concept of heritage as well as its management. Some problems are identified using these new approaches such as the economic expectation of the heritage to the region and the nation's development and the alienation of the community from the decision-making process or even the management of the heritage sites. This can reflect a lack of adequacy of the heritage interventions to the local context. In this way, the case studies analysis was carried out by a contraposition between the aspects referred above such as the economic expectation, the heritage intervention as an architectural project and the context where castles are integrated. The context analysis of each case study included, in the same way, some aspects referred to by these new approaches, namely the castle's significance to the community, their participation in the decision-making process, the social and economic characteristics of the context, etc. After that, analytic categories were drawn by the synthesis of that contraposition and constituted a common pattern for the individual and comparative analysis of all the case studies. Through the comparative analysis, the aim was to analyse convergent and divergent aspects which often appeared in the case studies. In this way, the intent was to gain some new perspectives to solve the problems found by the individual and comparative analysis according to the local resources and singularities, with a view to defining heritage as a process of construction of identity(ies). Concerning the pre-existent structure analysis, observation, field research and documental analysis were carried out. In relation to the heritage interventions, the main research techniques were observation, field research, photograph and documental analysis such as technical drawings, for example. In relation to the local context study, no specific data was found to analyse the local impact of each of the studied interventions. Therefore, various interviews of key-informants such as inhabitants and technicians of the local administrative institutions responsible for the castle maintenance and management were carried out.

\section{The case studies}

\subsection{Presentation of the analytic categories of analysis}

Figure 1 shows the key-ideas which result from the theoretical research carried out. On the left side, two ideas associated to heritage are presented. On one side, 
is the selection, an intrinsic process of the formation of identity(ies) which contemplates the choice of a certain values into a specific context or community, in which it should be understood how those values are passed on between different generations and, then, what is the role of the interpretation in that process. On the other side is the accumulation of heritage derived from the traditional concept of heritage, in which the selection constitutes a new approach to solve the problems generated by that accumulation. On the right side, the problems related to the heritage intervention which have arisen from the end of the twentieth century onwards are presented, namely the traditional concept of interpretation, which constitutes the construction of a certain message under an intrinsic value of the monument. This message contemplates the valorisation, per se, to adapt the monument to public fruition, where the authorship is evident several times as well as the intervention as an architectural project. In addition to this, it is expected that the heritage interventions generate economic benefits apart from the local communities and local resources. In this way, the case studies analysis was carried out by the contraposition between these key-ideas. Through this contraposition, which is marked by the red lines presented in figure 1, three analytic categories were drawn. The first analytic category was named Context/Community vs. Authorship/Architectural Project, the second one Context/Community vs. Economic Expectation and the last Associated Values vs. Intrinsic Values. These categories were divided into subcategories in order to achieve a more objective research of the different aspects, in that each subcategory was structured in a table by indicating the respective research technique, the source and the selection criteria.

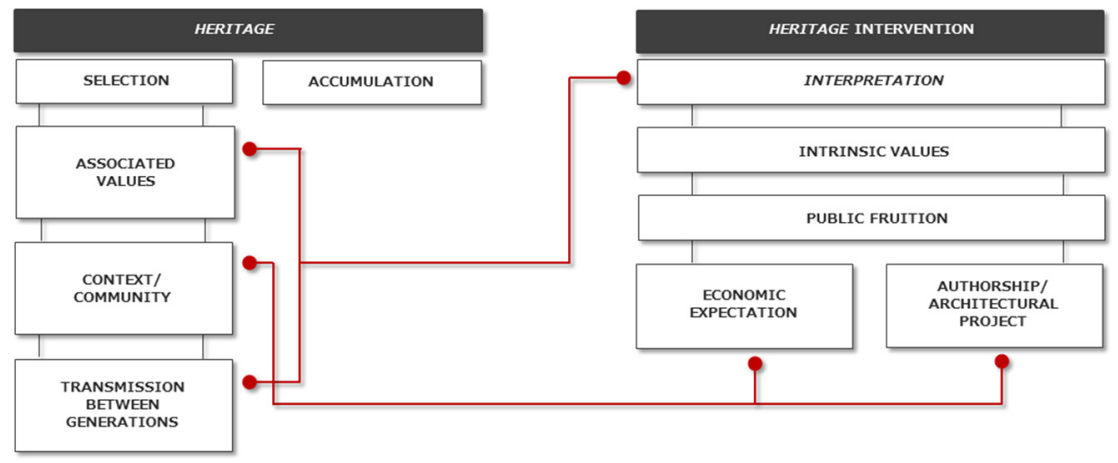

Figure 1: Synthesis of the theoretical fundamentals.

\subsection{The selection criteria}

The heritage interventions of the case studies are situated in the twentieth first century. The following criteria were taken into consideration when selecting the interventions: heritage intervention projects developed since 2001 and whose conclusion occurred by the end of 2012. As the present research project started in 2013, conclusion of the interventions by the end of 2012 was established as criteria 
to determine a minimum time framework to evaluate the impact of heritage interventions in the context in which they were integrated. Besides this, it was necessary that the castle had generated a settlement, still existent, either in a rural or urban framing in which it was possible to study the relation of the castle with the settlement nowadays. In this way, all the heritage interventions made on castles without a settlement were excluded. In addition to this, it was considered that heritage interventions of maintenance and structural conservation did not present relevant information to the present study, therefore only the interventions whose projects were constituted by an integral architectural project, with the inclusion of several aspects and based on the improvement of the conditions of the public fruition were chosen. This selection was made using the Portuguese castles "net" between the years 1350 and 1450, as defined by Monteiro [12].

A second selection was carried out correlating the criterions presented above with the geographical location, the territorial framing and intervention characteristics. In relation to the geographical location, at least one intervention was selected from each of the Portuguese regions to permit an analysis of different contexts and to discover if there is, or not, divergent aspects between them. In the same way, it was important to include rural and urban frameworks, where a rural framework is defined as not being the municipal capital and having less than 1000 inhabitants. In addition to that, at least two cases in each of the frameworks must be selected. Lastly, interventions which presented reversibility and a new approach when it came to concept and programme were taken into consideration over interventions with just museum programmes of pre-existent spaces. As a result of this selection process seven heritage interventions were selected, as figure 2 shows, namely the interventions on Mogadouro castle (1), Trancoso castle (2), Celorico da Beira castle (3), Castelo Novo castle (4), Amieira do Tejo Castle (5), Portalegre castle (6) and finally Silves castle (7).

\subsection{Individual presentation of the case studies}

\subsubsection{Mogadouro castle}

Mogadouro castle is situated in the north of Portugal, near the Spanish border. The castle was part of a territorial space managed by Templars, who had been given the castle in 1145 . The construction of the castle began in the same century. Mogadouro is nowadays a small town and has 3549 inhabitants. The main objective of the heritage intervention was the redesign of the surrounding urban space as well as the space into the castle walls. An intervention on the keep tower was undertaken to permit public access.

\subsubsection{Trancoso castle}

The town of Trancoso is on a plateau, situated on a 900 meters elevation. The large economic activity constituted the main factor that led to the town's development. Besides this, the town has a considerable historical relevance due to the several events related to Portuguese Military history. As Mogadouro castle, Trancoso castle also was Templar property, having been earlier constructed by Muslims, in the tenth century. The castle forms part of the defence line of the central region of 


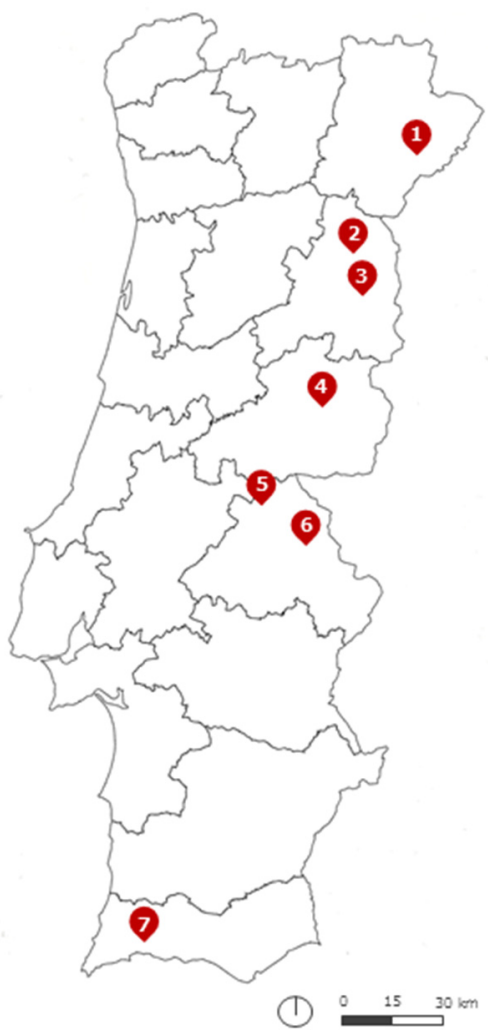

Figure 2: Location of the case studies.

Portugal. The heritage intervention was focused on the creation of conditions for public fruition as well as a construction of an outdoor auditorium and the implementation of accessibility to the keep tower. Exposition spaces were also created inside the keep tower.

\subsubsection{Celorico da Beira castle}

Celorico da Beira castle is settled on the north hillside of the Serra da Estrela, in the centre of Portugal. The town was also situated on an ancient road which connected the city of Coimbra to Portuguese capital, Lisbon. In this way, Celorico da Beira constituted a relevant strategy site to the defence of Coimbra. The castle was constructed in the twelfth century and forms part of the same defence line as the Trancoso castle. Besides this, the castle was the main factor for the settlement's development. Nowadays, due to its geographical location, the town has an alarming lack of resident population, a decrease which is notable when compared to the population in 1911. The heritage intervention is constituted mainly by an implementation of exposition spaces as well as a documental research centre in the keep tower. Besides this, a small auditorium was constructed within the castle walls and a visiting circuit established. 


\subsubsection{Castelo Novo castle}

The small village of Castelo Novo was formed after the abandonment of the first settlement named Castelo Velho. The village was established as the centre of the municipality from the thirteenth century onwards and the castle, which was given to the Templars, was constructed in that period. Besides this, the castle forms part of another defence line in the centre of Portugal. From the sixteenth century onward, the town progressively lost its importance as the municipality centre and nowadays the village faces an alarming population decrease, having only 406 inhabitants. The heritage intervention was focused on the creation of accessibility to all spaces of the castle through the installation of circuits. A new volume to the public reception as well a new volume to an auditorium were constructed.

\subsubsection{Amieira do Tejo castle}

Amiera do Tejo is a small village which, as Castelo Novo, presents a serious population decrease, having only 241 inhabitants. The village is situated on the south border of the river Tagus, in the Alentejo region. Due to the good conditions of navigability this was an important strategic site of fluvial crossing between two regions of Portugal and resulted in its area's settlement and its consecutive development. The region was given to Hospitallers Military Order in 1194. The castle was constructed later, in the fourteenth century and was part of the defence line of the river Tagus as with so many other castles. The main objective of the heritage intervention was the rehabilitation of the keep tower for public reception and exposition spaces.

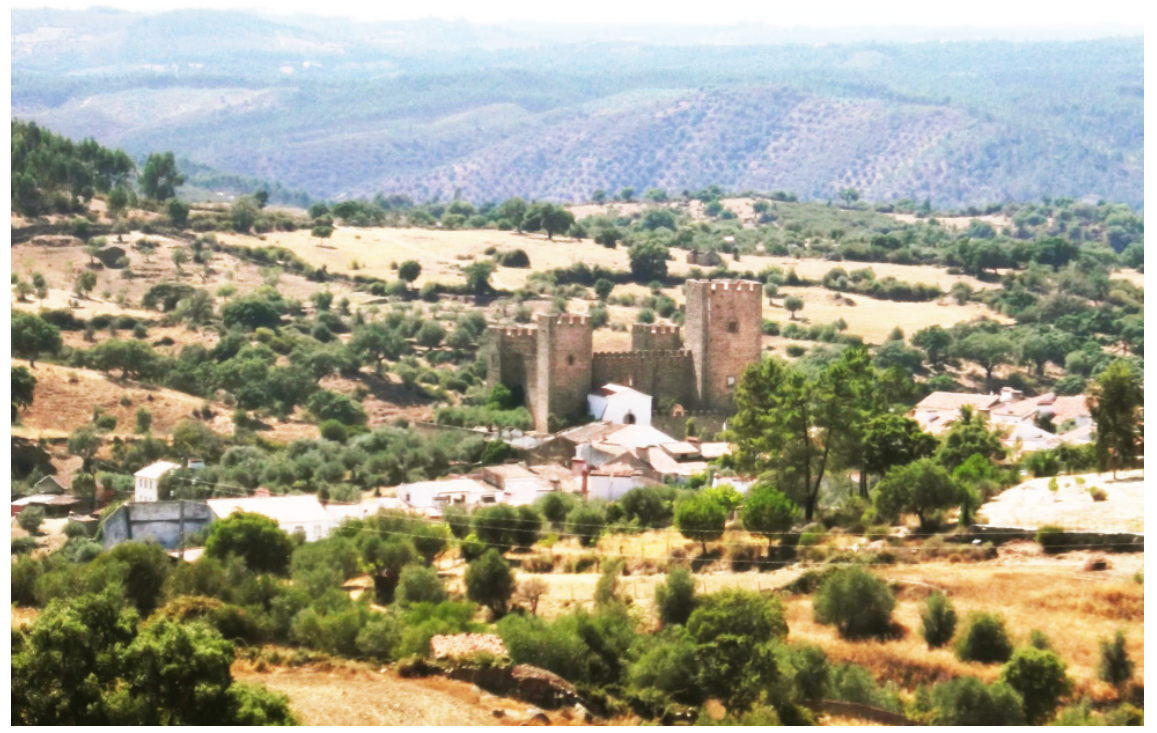

Figure 3: Amieira do Tejo castle, 2013. 


\subsubsection{Portalegre castle}

The city of Portalegre is protected by Serra de São Mamede, situated in the Alentejo region. This natural protection allowed a settlement and a privileged view of the surrounding territory. The castle was constructed in the thirteenth century and forms part of a secondary defence line of the Alentejo region as well as the boundary with Spain. The heritage intervention presents a construction of a new volume, of large dimensions, which contains various space types such as public reception, restaurant, cafeteria and exposition spaces. An auditorium with galleries was also installed within the castle walls.

\subsubsection{Silves castle}

The city of Silves was one of the main Muslim cities in the Iberian Peninsula and its castle was constructed under Muslim domain in the eighth century. Silves was conquered by the Portuguese in the twelfth century. The castle constitutes one of the larger medieval Portuguese military structures and was built using a unique local stone and rammed earth. Besides this, the castle presents characteristics of the Muslim military structures as for example a large cistern inside the space defined by the walls. The Castle is a much visited site throughout the year, a fact which is due to the location of Silves in the Algarve region, one of the most visited regions of Portugal. The intervention on the Silves Castle was made in various locations. Within the castle walls an events area was constructed, visiting circuits to the archaeological remains were established and a tea house was also constructed. Finally, in the various existing towers exposition spaces were installed, as well as inside the cistern.

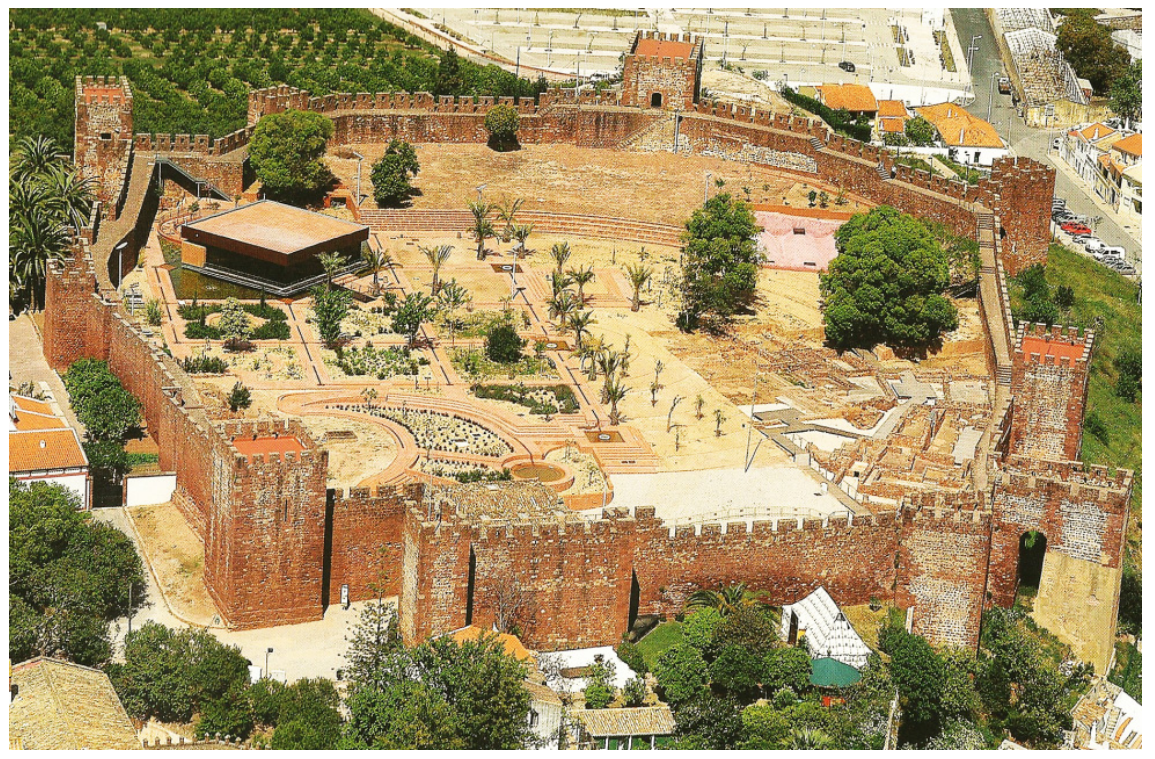

Figure 4: Silves castle, n/d. Author(s): FG+SG. Source: Ferreira, J., (ed). Silves Polis, SILVESPOLIS: Silves, 2009. 


\subsection{Comparative analysis}

Firstly, it was necessary to define which categories could allow an effective comparative analysis throughout all the heritage interventions. So, only the analytic categories named Context/Community vs. Authorship/Architectural Project and Context/Community vs. Economic Expectation were taken in order to compare the conclusions from each individual analysis. The third one, named Associated Values vs. Intrinsic Values, was not considered, in the comparative analysis, because the values which are associated to each castle depend on the singular characteristics of its context, in that it is not possible to make a comparison. As for the first analytic category, aspects such as the heritage intervention programme and the options of reversibility, the interventions propose/justification, the participation of the local community in the decisionmaking process and the existence of a maintenance planning were compared. In the second category, the existence of intention, in the project, that the heritage intervention could generate economic benefits and the attraction of more visitants as a solution for the local trade development were also compared. Starting with the first analytic category mentioned above, there is an evidence of some changes in the heritage intervention programmes of the twenty first century when compared with the previous decade's programmes. Almost all the analysed programmes intend to adapt the castle to the public fruition by using platforms to define visit circuits, installation of multifunctional open air auditoriums and the construction of new volumes, outside the castle, in order to provide public reception spaces as well as other adaptable spaces. So, programmes as hotels or installation of municipal office services were progressively left out in order to adapt the castles to a cultural programme throughout the installation of multifunctional spaces with a reversible condition by using materials such as wood and metal structures. In what concerns internal spaces, those are adapted, in almost all of the case studies, to exhibition spaces, stressing the importance of the public fruition needs as purpose in the contemporary heritage interventions. However, according to the analysis results of inhabitants interviews, the architects' intentions in providing the castles with adaptable spaces to dynamise cultural activities in the respective villages were not achieved: a significant quantity of the designed spaces is not used, is inactive, or there is a lack of cultural activities agenda. This aspect means that the architecture's heritage project was not conceived as a response to the singularities of the local community, where there is also a lack of preview analysis for the existence of other cultural spaces in those villages. Another important aspect is that in almost all of the cases, the respective interventions were possible due to the access to communitarian funds. This means that the invested financial resources in some heritage interventions were not used in according to the financial resources of the local government available for the castle's maintenance. The castles are situated in regions which present several differences in terms of available economic resources. The interviewed inhabitants and technicians mentioned that some castles face maintenance problems. Besides this, they are also concerned with the lack of future financial resources to ensure maintenance. In some castles, their maintenance is assured by municipality, which 
has been a question of concern because these institutions face a financial difficulty which is reflected by the lack of continuation in the castles' maintenance. In addition to that, there is not a link between the communitarian financial resources available to the heritage interventions and the financial resources available for their maintenance in the medium or long term: the municipalities face serious problems in this subject due to the use of expensive architectural solutions or materials by architects in the respective interventions which also means that the necessity of a heritage intervention was only justified by the access to those monetary funds. As a result, isolated interventions were carried out based on the strict pre-existent structure specificities, where no spaces for local communal activities were considered. In this way, it is possible to conclude that interventions on castles were interpreted as being a pretext or opportunity for architectural experiments in form and conceptual ideas with a lack of restriction, in that authorship is stressed. So, the heritage interventions on Portuguese castles are still conceived as a strict architecture's exercise. In this way, there are no significant differences concerning the justification of said interventions. This shows that other strategies with a different purpose beyond the creation of conditions for public fruition, namely with the participation of different social actors and a real response to the context, are practically inexistent. So, to achieve a different strategy of the heritage interventions, the effective participation of the community would be necessary: a fact that was not evident in any of the cases. According to the results of the interviews, there was no opportunity for a civic participation on the decision-making process, and in the Silves castle intervention there also was a lack of dialog between the local administrations, the architect responsible for the project and public institutions related to national heritage. Although several interviewed inhabitants stressed the importance of a civic participation in the decision-making process, no strategies exist to allow this kind of contribution. There was also an evidence of a lack of knowledge/information about the authorship of the heritage intervention in some cases. Some of the interventions were designed by architects from the local administrations, and the others were designed by private architects' ateliers. In the few cases where the community knows the authorship or some facts about the project, the architect is not the local technician, fact which proves a lack of dialog between different agents: it would be expected that the projects designed by local technicians should result in a more effective adaptation of the castle's heritage intervention to the local context. Introducing now the second analytic category, based on the economic expectation that the heritage interventions can generate, as almost all the heritage interventions are based on a public fruition needs and a cultural programme, it indirectly shows that an increased number of visitors to the region are expected and, therefore, would generate economic benefits to local trade. However, the contexts where the castles are integrated present significant differences in this subject. In Amieira do Tejo, for example, the castle has a large importance as the main factor to the revitalization of the small village due to the fact that the village has few inhabitants and the economic activity is almost inexistent. After the heritage intervention, it was expected that the number of visitors would increase. However, this expectation did not happen and it proves that a different approach 
is necessary and must include other local potential resources. In a different case, Silves, the main objective of the castle's heritage intervention was only to improve some debilities the castle presented in relation to public's reception and fruition needs because the large number of visits which the castle generates has already impacted local trade. In spite of that, and through the interviews analysis, it was evident that the castle is not, per se, the solution for the local development. In the other case studies, a very significant number of the interviewees considerer that the castle and the recent heritage intervention do not constitute a factor with a significant impact on the local development, which contradicts the general economic expectation that was one of the motives of the heritage interventions. Finally, it is important to point out that according to the results achieved by the individual analysis of each castle's heritage intervention it was observed that castles have multiple meanings to each community, where, in some of the cases, divergent views exist in relation to the historical and artistic value(s), putting into question what the message and values each heritage intervention attempts to transmit. This question has implications in the way the community relates itself with the castle: if a community does not value the castle for its traditional, historical or artistic values, it means that the community will not contribute to its maintenance and sustainability due to it not recognizing the value in doing so.

\section{Conclusion}

The heritage intervention on Portuguese castles may no longer only constitute an isolated architectural intervention but rather a multidisciplinary process in which meditation between the associated values from the local community and the historical and artistic values traditionally attached to the monuments is achieved. In addition to this, a different management process of short or long duration may have to be developed to advance the heritage transmission between the different generations of a community; a fact which implies the on-going work between technicians and the community. The creation of the message which is presented to the public based on the historical and artistic values may no longer be pertinent due to the multiplicity of meanings that the same artefact can represent to different people. In this way, a heritage intervention on Portuguese castles will have to be the result of a deep knowledge of the local resources as well as the singularities of each context where the castles are integrated. Finally, to allow the application of the process mentioned above a development of a new methodology will be required.

\section{References}

[1] Tomé, M., Património e restauro em Portugal (1920-1995), Faculdade da Universidade do Porto: Porto, 2002.

[2] Neto, M., Restaurar os monumentos da Nação entre 1932 e 1964. 100 anos do património: memória e identidade, coord. J. Custódio, IGESPAR: Lisboa, pp. 157-166, 2010. 
[3] Aguiar, J., Após Veneza: do restauro estilístico para o restauro científico. 100 anos do património: memória e identidade, coord. J. Custódio, IGESPAR: Lisboa, pp. 219-235, 2010.

[4] Pereira, P., Intervenções no património: nova política (1997-2000), IPPAR: Lisboa, 1997.

[5] Harrison, R., Heritage: critical approaches, Routledge: Oxon, 2013.

[6] Santos, J., Anamnesis del Castillo como bien patrimonial: construcción de la imagen, forma y (re)funcionalización en la rehabilitavión de fortificaciones medievales en Portugal (unpublished doctoral thesis), Universidad de Alcalá, Spain, 2012.

[7] Folgado, D., Património inclusivo. Das expectativas aos desafios. 100 anos do património: memória e identidade, coord. J. Custódio, IGESPAR: Lisboa, pp. 323-335, 2010.

[8] Fernandes, J., O impacte da Carta de Veneza na conservação e restauro do património arquitectónico. 100 anos do património: memória e identidade, coord. J. Custódio, IGESPAR: Lisboa, pp. 237-257, 2010.

[9] Smith, L., Uses of heritage, Routledge: Oxon, 2006.

[10] Jokilehto, J., A History of architectural conservation, Elsevier: Oxford, p. 318, 2004.

[11] Yin, R., Case study research. Design and methods, Sage publications: California, 2003.

[12] Monteiro, J., Os castelos portugueses dos finais da Idade Média, Edições Colibri: Coimbra, 1999. 